\title{
Implementasi Pembelajaran Matematika Berbasis Kurikulum Jaringan Sekolah Islam Terpadu (JSIT) Dalam Membentuk Karakter Siswa
}

\author{
Tika Hildani $^{1}$, Islamiani Safitri ${ }^{2}$ \\ ${ }_{1,2}$ Program Studi Pendidikan Matematika, Universitas Labuhanbatu, \\ J1. Sisingamangaraja No 126 A KM 3.5 Aek Tapa, Rantauprapat, Indonesia \\ tikahildani1999@gmail.com
}

\begin{abstract}
Integrated Islamic School emphasizes on the planting of religious subjects such as religion, akhlaq and practical worship in accordance with the theory of education. He aims to build the character and morality of students with islamic colors reflected in the way of thinking, attitudes, and practices of daily life. This study aims to describe and explore Mathematics Teaching based on the Curriculum of The Network of Integrated Islamic Schools (JSIT) as well as describe the character of students in their implementation. The focus of the research was SMP IT Arrozaq. This research uses qualitative approach that is descriptive. Research instrument is the researcher itself which is equipped with interview sheet, observation sheet, and check list. While the techniques of data collection using interviews, observations, and documentation. The results of this study showed that the implementation of mathematics learning based on the curriculum of The Trepadu Islamic School Network (JSIT) at SMP IT Arrozaq always integrates Islamic values or sciences in mathematics learning and is highly guided by the Qur'an. The implications of the implementation of the learning form students who have a good personality and morals, and have a clean faith. The character values that appear can be seen from the daily activities of students such as performing congregational prayers, recitation, and dhikr together. So basically all the applications that students do and implement, can be embraced to get a good.
\end{abstract}

Keywords: Math learning; JSIT curriculum; student character.

\begin{abstract}
Abstrak
Sekolah Islam Terpadu menekankan pada penanaman mata pelajaran keagamaan seperti akidah, akhlaq dan ibadah praktis yang sesuai dengan teori pendidikan. Ia bertujuan untuk membangun karakter dan moralitas siswa dengan warna islam yang direfleksikan dalam cara berpikir, sikap, dan praktik kehidupan sehari-hari. Penelitian ini bertujuan untuk mendeskripsikan dan mengeksplorasi. Pengajaran Matematika berbasis kurikulum Jaringan Sekolah Islam Terpadu (JSIT) serta mendeskripisikan karakter siswa dalam implementasinya. Fokus penelitian adalah SMP IT Arrozaq. Penelitian ini menggunakan pendekatan kualitatif yang bersifat deskriptif. instrument penelitian adalah peneliti itu sendiri yang dilengkapi dengan lembar wawancara, lembar observasi, dan daftar check. Sedangkan tekhnik pengumpulan datanya menggunakan wawancara, observasi, dan dokumentasi. Hasil penelitian ini menunjukkan bahwa implementasi pembelajaran matematika berbasis kurikulum Jaringan Sekolah Islam Trepadu (JSIT) di SMP IT Arrozaq selalu mengintegrasikan nilai-nilai atau ilmu Islam di dalam pembelajaran matematika dan sangat berpedoman pada Al-Qur'an. Impilkasi dari implementasi pembelajaran tersebut membentuk siswa yang memiliki kepribadian dan akhlak yang baik, serta memiliki akidah yang bersih. Nilai-nilai karakter yang muncul dapat di lihat dari kegiatan siswa sehari-hari seperti melaksanakan sholat berjamaah, tilawah, dan dzikir bersama. Jadi pada dasarnya semua penerapan yang dilakukan dan dilaksanakan siswa itu, dapat dirangkul untuk mendapatkan suatu kebaikan.
\end{abstract}

Kata kunci: Pembelajaran matematika; kurikulum JSIT; karakter siswa

Copyright (c) 2021 Tika Hildani, Islamiani Safitri

$\triangle$ Corresponding author: Tika Hildani

Email Address: tikahildani1999@gmail.com (Jl. Sisingamangaraja No 126 A KM 3.5 Aek Tapa, Rantauprapat, Indonesia) Received 09 Maret 2021, Accepted 16 Maret 2021, Published 19 Maret 2021

\section{PENDAHULUAN}

Pendidikan merupakan bagian dari perjalanan hidup manusia yang mempunyai suatu keinginan untuk membawa atau memberikan penguatan dan kemajuan bagi setiap bangsa dan Negara, termasuk bangsa Indonesia. Hal tersebut ditegaskan dalam UU N0. 20 tahun 2003 tentang Sistem Pendidikan Nasional, Pasal 3 menyatakan bahwa: "Pendidikan Nasional berfungsi untuk mengembangkan kemampuan serta membentuk watak dan peradaban bangsa yang bermartabat dalam rangka 
mencerdaskan kehidupan bangsa yang bertujuan untuk berkembangnya potensi pada peserta didik agar menjadi manusia yang ,1) beriman dan bertaqwa kepada Tuhan Yang Maha Esa, 2) berakhlaq mulia, 3) sehat, 4) berilmu, 5) cakap, 6) kreatif, 7) mandiri dan 8) menjadi warga yang demokratis serta memiliki sifat yang bertanggung jawab. Maka dari itu, sangat perlu dilakukan dan harus diterapkan suatu proses pendidikan agar nilai-nilai (karakter) tersebut dapat tertanam dalam diri peserta didik (Erwanto, 2019). Pendidikan Islam adalah pendidikan yang bertujuan untuk membentuk pribadi seorang muslim seutuhnya atau holistik, dan dapat mengembangkan seluruh potensi manusia, baik yang berbentuk jasmaniah maupun rohaniah, menumbuhsuburkan hubungan yang harmonis dalam setiap kepribadian dengan Allah, manusia dan alam semesta (Fahri, 2018).

Pendidikan karakter adalah pendidikan yang menanamkan suatu kebiasaan-kebiasaan tentang hal-hal yang baik terpancar dari dalam diri manusia baik sifat-sifat kejiwaan, akhlak maupun budi pekerti yang baik yang di refleksikan kedalam sikap dan tingkah laku secara terus-menerus. Pembentukan karakter tersebut juga dapat dilakukan melalui keteladan, intervensi, pembiasaan dan pengutan yang dilakukan secara kontinu sehingga menghasilkan budaya dari sekolah titu sendiri (Nizarani, 2019). Pada dasarnya nilai-nilai karakter yang perlu dikembangkan dalam mata pelajaran matematika adalah nilai-nilai positif yang tidak terlepas dari hakikat matematika itu sendiri (Maryati, 2017).

Sekolah Islam Terpadu memiliki dasar dari kata terpadu itu sendiri. Terpadu merupakan simbol yang paling utama yang digunakan oleh sekolah tersebut. Terpadu memiliki arti bahwa adanya integrasi antara ilmu umum serta ilmu agama. Sekolah Islam Terpadu juga menganggap bahwa seluruh mata pelajaran itu sejatinya tidak dapat terlepas dari pendidikan agama, karena agama memiliki tujuan akhir yaitu menjadikan setiap siswa untuk bertauhid (Afrizal, 2011). Penggunaan kata terpadu juga merupakan sebuah usaha yang muncul dari suatu konsep yang digunakan untuk membangun citra sekolah Islam Terpadu itu sendiri, yaitu sebuah citra bahwa, selain mempelajari serta mengembangkan pendidikan sains dan teknologi, sekolah ini juga dituntut untuk melaksanakan pembelajaran dan pengembangan pendidikan agama secara utuh. Kata terpadu menjadi sebuah dasar atau pedoman dalam suatu sekolah yang dijadikan simbol karena adanya keterpaduan antara pengembangan sains dan teknologi dengan ilmu-ilmu keIslaman. Pendidikan dalam Sekolah Islam Terpadu memiliki tujuan umum yaitu, melakukan pembinaan kepada peserta didiknya agar dapat menjadi insan yang bertakwa, yang tidak hanya dalam kecerdasan namun juga berakhlak mulia, serta memiliki keterampilan yang memberi maslahat/menghindarkan kemudharatan bagi umat manusia (Pertiwi \& Marsigit, 2017).

Perbedaan antara Sekolah Umum dengan sekolah Islam Terpadu terletak pada ke'khasannya', sejak kemunculan Sekolah Islam Terpadu pada tahun 1992 yang ingin mewujudkan model sekolah yang mampu memadupadankan ilmu qauli dan qauni menjadi satu kesatuan dlam proses pembelajaran, sehingga diharapkan melalui sekolah ini terlahirlah peserta didik yang berkualitas, baik secara akademik maupun secara mental spiritual (Marannu, 2017). Kurikulum yaitu seperangkat rencana dan pengaturan mengenai isi dan bahan pelajaran serta cara yang digunakan sebagai pedoman dalam penyelenggaraan 
suatu kegiatan proses pembelajaran untuk mencapai tujuan pendidikan tertentu. Kurikulum terpadu adalah suatu kegiatan untuk menata keterpaduan dalam berbagai materi mata pelajaran melalui tema lintas dalam bidang untuk membentuk suatu keseluruhan yang dapat bermakna, sehingga batas antara berbagai bidang studi tidaklah ketat atau boleh dikatakan tidak ada. Kurikulum Jaringan Sekolah Islam Terpadu (JSIT) sesungguhnya melengkapi kurikulum nasional. Dalam kurikulum Jaringan Sekolah Islam Terpadu (JSIT) seluruh mata pelajaran wajib melakukan dan melaksanakan internalisasi pada nilai-nilai Islam didalamnya (Robingatin, 2015).

Sekolah Islam Terpadu (SIT) pada hakikatnya adalah sekolah yang mengimplementasikan konsep dalam pendidikan Islam yang berlandaskan Alquran dan As Sunnah serta dilandasi oleh Undang-undang Sistem Pendidikan Nasional. Konsep operasional SIT merupakan akumulasi dari proses pembudayaan, pewarisan dan pengembangan ajaran agama Islam, budaya dan peradaban Islam dari generasi ke generasi. Istilah kata "terpadu" dalam SIT dimaksudkan sebagai penguat (taukid) dari Islam itu sendiri. Maksudnya yaitu Islam yang utuh, menyeluruh, integral, bukan parsial, syumuliah bukan juz'iyah. Hal ini menjadi semangat utama dalam gerak dakwah di bidang pendidikan ini sebagai “perlawanan” terhadap pemahaman sekuler, dikotomi, dan juz’iyah (JSIT Indonesia, 2017).

Sekolah Islam Terpadu, dibutuhkan dalam sebuah lembaga pendidikan alternatif untuk dapat menjembatani dualisme dalam sistem pendidikan nasional. Yakni tidak hanya dalam penguasaan sains dan teknologi semata, atau sebaliknya, tetapi hanya penguasaan ilmu agama itu sendiri, siswa perlu dibekali sains dan teknologi dan ilmu agama secara utuh dengan pendekatan epistemology atau asal muasal yang integratif sehingga dapat menghasilkan siswa dengan kepribadian yang utuh pula (Suyatno, 2015). Sekolah Islam Terpadu merupakan suatu gambaran dari sebuah inovasi pendidikan Islam di era modern yang sedang marak saat ini. Model ini diharapkan bisa menjadi suatu model pendidikan Islam yang mampu memadupadankan dua misi besar dalam pendidikan yaitu transinternalisasi nilai-nilai ilahiyah dan nilai-nilai dunia kemodrenan (Yusup, 2018).

Kurikulum dalam pengembangan Sekolah Islam Terpadu sangat berperan penting dalam proses penggambaran konsep keterpaduannya. Seluruh sekolah Islam terpadu yang tersebar di Indonesia telah memiliki kurikulum khas Sekolah Islam terpadu. Kurikulum pada sekolah Islam terpadu tersebut dinamakan dengan (kurikulum ke-Islam Terpadu-an). Dan sudah merupakan kurikulum yang telah dirumuskan oleh pengurus pusat JSIT lewat musyawarah nasional, dan sudah disetujui oleh dewan pembina yang kemudian dapat diteruskan ataupun harus diterapkan oleh seluruh sekolah yang bergabung dalam Jaringan Sekolah Islam Terpadu. Kurikulum sekolah Islam terpadu berhasil membawa dampak yang cukup signifikan dalam proses belajaran mengajar yang telah berjalan langsung di dalam suatu kelas. Dampak ini biasa disebut dengan dampak Islamisasi kelas atau dampak Islamisasi pembelajaran. Disebut demikian karena kurikulum sekolah Islam terpadu sudah mampu mengintegrasikan nilai-nilai Islam ke dalam berbagai mata pelajaran non pendidikan agama Islam. Bahkan indikator pencapain belajar siswa pun tidak hanya diukur dengan tercapainya sebuah kompetensi, akan tetapi yang lebih ditekankan yaitu sejauh mana siswa tersebut dapat berkomitmen 
dengan pembelajaran nilai-nilai Islam yang telah mereka pelajari (Rojii et al., 2019). Adapun tujuan dari penelitian ini adalah untuk mendeskripsikan Pengajaran Matematika berbasis kurikulum JSIT serta mendeskripisikan karakter siswa dalam implementasinya.

\section{METODE}

Penelitian ini mengunakan metode penelitian kualitatif yaitu penelitian yang bermaksud untuk memahami fenomena tentang apa yang dialami oleh subjek penelitian, misalnya perilaku, persepsi, motivasi tindakan, dan lain-lain, secara holistic (menyeluruh) dengan cara deskripsi dalam bentuk katakata atau bahasa, pada suatu konteks khusus yang alamiah dan dengan memanfaatkan berbagai metode alamiah. Jenis pendekatan kualitatif yang digunakan adalah deskriptif yaitu menganalisis, menggambarkan dan meringkas berbagai kondisi, situasi dari berbagai data yang dikumpulkan berupa hasil wawancara atau pengamatan mengenai masalah yang diteliti yang terjadi dilapangan. Dalam penelitian ini yang akan dideskripsikan adalah bagaimana penerapan pembelajaran matematika berbasis kurikulum JSIT serta ingin mengetahui karakter pembentukan siswa di SMPIT Arrozaq.

Sasaran dan lokasi penelitian ini adalah sekolah Islam terpadu dengan jenjang satuan pendidikan sekolah menengah pertama. Sekolah Islam terpadu yang dimaksud adalah sekolah menengah pertama Islam terpadu (SMP IT) Arrozaq. Subjek penelitian adalah bidang kurikulum dan guru pendidikan matematika.

Instrument penelitian adalah peneliti itu sendiri. Sedangkan tekhnik pengumpulan datanya menggunakan wawancara, observasi, dan dokumentasi. Wawancara adalah percakapan yang dilakukan oleh dua pihak, yaitu pewawancara (interviewer) yang mengajukan pertanyaan dan terwawancara (interview) yang memberikan jawaban atas pertanyaan tersebut. Teknik wawancara yang dilakukan adalah wawancara terstruktur, artinya pewawancara menetapkan sendiri masalah dan pertanyaanpertanyaan yang akan diajukan. Berdasarkan teknik wawancara terstruktur, wawancara ini diajukan untuk melihat bagaimana penerapan pembelajaran metematika berbasis kurikulum JSIT dalam pembentukan karakter pada peserta didik di SMPIT Arrozaq.

Observasi merupakan aktivitas penelitian dalam rangka mengumpulkan suatu data yang berkaitan dengan suatu masalah penelitian melalui proses pengamatan secara langsung di lapangan. Jenis observasi yang digunakan yaitu observasi tak berstruktur, observasi tidak berstruktur artinya observasi yang tidak dipersiapkan secara sistematis tentang apa yang akan diobservasi. Peneliti dapat melakukan pengamatan bebas, mencatat apa yang tertarik, melakukan analisis dan kemudian membuat kesimpulan untuk melihat bagaimana penerapan pembelajaran metematika berbasis kurikulum JSIT dalam pembentukan karakter pada peserta didik yang ada di SMPIT Arrozaq.

Dokumentasi merupakan teknik pengumpulan data melalui pengumpulan dokumen-dokumen yang diperlukan dan berhubungan dengan masalah yang diteliti untuk ditelaah secara intens sehingga dapat mendukung dan menambah kepercayaan dan pembuktian suatu masalah. Dokumentasi digunakan untuk mendapatkan gambaran dari sudut pandang subjek melalui suatu media tertulis dan dokumen lainnya 
seperti gambaran umum sekolah, struktur organisasi sekolah, keadaan guru, peserta didik dan foto-foto lainnya. Metode dokumentasi dilakukan untuk mendapatkan data-data yang belum didapatkan melalui metode wawancara dan observasi.

Pada penelitian ini data yang digunakan yaitu data primer dan sekunder. Data primer adalah data yang berasal dari sumber asli, data ini dicari melalui narasumber ataupun responden, yaitu orang yang dijadikan objek penelitian atau orang yang kita jadikan sebagai sarana mendapatkan informasi ataupun data siswa di SMPIT Arrozaq. Sedangkan data sekunder adalah data yang telah tersedia dalam berbagai bentuk umum berupa bukti, catatan atau laporan yang telah tersusun dalam arsip (data documenter) yang dipublikasikan dan yang tidak dipublikasikan. Dalam penelitian ini data sekunder didapat dari lembaga maupun pihak-pihak yang berkaitan dengan penelitian ini.

\section{Teknik Analasis Data}

Teknik analisis data yang digunakan adalah analisis Model Miles dan Huberman dimana teknik data kualitatif yang umum digunakan oleh peneliti. Adapun proses pengumpulan data dan analisis data serta pengambilan kesimpulan yaitu:

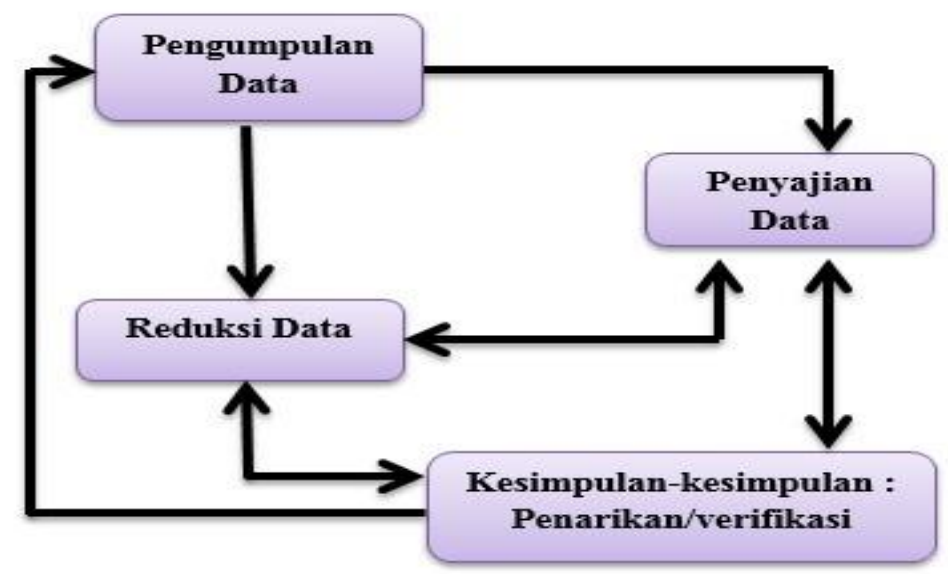

Gambar 1. Komponen Dalam Analisis Data (Interactive Model)

\section{Pengumpulan Data}

Pada tahap ini yang perlu dipenuhi antara lain rancangan atau scenario penelitian, memilih dan menetapkan setting (latar) penelitian, mengurus perijinan, memilih dan menetapkan informan (sumber data), menetapkan strategi dan teknik pengumpulan data, serta, menyiapakan sarana dan prasarana penelitian. Pengumpulan data dilakukan dengan menemui sumber data. Hal-hal yang perlu diperhatikan saat melakukan pengumpulan data adalah menciptakan hubungan yang baik antara peneliti dengan sumber data. Hal ini terkait dengan teknik pengumpulan data yang akan digunakan misalnya observasi, wawancara atau pengamatan

\section{Penyajian Data/ Display}


Dalam penelitian kualitatif, penyajian data bisa dilakukan dalam bentuk uraian singkat, bagan, hubungan antar kategori, flowchart dan sejenisnya. Dalam hal ini Miles and Huberman (1984) menyatakan "yang paling sering digunakan untuk menyajikan data dalam penelitian kualitatif adalah dengan teks yang bersifat naratif. Dengan mendisplaykan data, maka memudahkan untuk memahami apa yang terjadi, merencanakan kerja selanjutnya berdasarkan apa yang telah difahami tersebut. Miles and Huberman(1984)selanjutnya disarankan, dalam melakukan display data selain dengan teks yang naratif, juga dapat berupa, grafik, matrik, network (jejaring kerja) dan chart (Sugiono, 2009).

\section{Reduksi Data (Data Reduction)}

Reduksi data adalah merupakan proses berfikir sensitive yang memerlukan kecerdasan dan keluasan dan kedalaman wawasan yang tinggi. Dalam mereduksi data, setiap peneliti akan dipandu oleh tujuan yang akan dicapai. Tujuan utama dari penelitian kualitatif adalah pada temuan. Oleh karena itu, kalau peneliti dalam melakukan penelitian, menemukan segala sesuatu yang dipandang asing, tidak dikenal, belum memiliki pola, justru itulah yang harus dijadikan perhatian peneliti dalam melakukan reduksi data (Sugiono, 2009).

\section{Verifikasi Data (Conclusions Drowing/Verifiying)}

Langkah terakhir dalam teknik analisis data adalah verifikasi data. Verifikasi data dilakukan apabila kesimpulan awal yang dikemukan masih bersifat sementara, dan akan ada perubahan-perubahan bila tidak dibarengi dengan bukti-bukti pendukung yang kuat untuk mendukung pada tahap pengumpulan data berikutnya. Bila kesimpulan yag dikemukan pada tahap awal, didukung dengan bukti-bukti yang valid dan konsisten saat penelitian kembali ke lapangan mengumpulkan data, maka kesimpulan yang dikemukan merupakan kesimpulan yang kredibel atau dapat dipercaya (Sugiono, 2009).

\section{Keabsahan Data}

Keabsahan data merupakan konsep penting yang diperbaharui dari konsep kesahihan (validitas) dan keandalan (reabilitas) menurut versi 'positivisme' dan disesuaikan dengan tuntunan pengetahuan, kriteria dan paradigmanya sendiri. Pada awalnya keabsahan data harus dilihat dari segi kriteria yang digunakan oleh non-kualitatif yang menggunakan 'validitas internal', 'validitas eksternal' dan'reliabilitas'. Pada penelitian ini keabsahan yang digunakan ialah Triangulasi dimana triangulasi adalah teknik pemeriksaan keabsahan data yang memanfaatkan sesuatu yang lain dari luar data itu untuk keprluan pengecekan atau sebagai pembanding terhadap suatu data. Menurut Moleong (2001) penelitian yang menggunakan teknik trigulasi dalam pemeriksan melalui sumbernya artinya membenadingkan atau mengecek ulang derajat kepercayaan suatu informasi yang diproleh melalui waktu dan alat yang berbeda. Triagulasi dilakukan melalui wawancara, observasi tidak langsung yang dilakukan dalam bentuk pengamatan dari beberapa kejadian, pada teknik ini untuk melengkapi dalam memproleh data primer dan data sekunder, observasi dan interview untuk menjaring data primer yang berkaitan data 
penelitian, sementara studi dokumentasi digunakan untuk menjaring data sekunder yang dapat diangkat dari berbagai dokumentasi yang berhubungan dengan data penelitian (LEXY J. MOLEONG, 2013).

\section{HASIL DAN DISKUSI}

\section{Kurikulum JSIT}

Kurikulum sekolah Islam terpadu merupakan keterpaduan dari kurikulum nasional. Kurikulum kekhasan Sekolah Islam Terpadu memiliki kekhasann yang bersifat mandiri, ini berarti kompetensi tersebut memang tidak ada pada kurikulum nasional, atau bisa dikatakan bersifat pengembangan kompetensi tersebut ada pada kurikulum nasional, namun diperluas atau diperdalam lagi oleh JSIT Indonesia (Indra \& Barat, n.d.).

Suatu keberhasilan sebuah lembaga pendidikan dalam mencapai tujuan pendidikan yang di inginkan salah satunya adalah bagaimana lembaga terserbut mengemas atau menerapkan kurikulumnya, pada hakikatnya kurikulum itu ada yang bersifat fungsional dan yang bersifat rencana, artinya kurikulum bukan hanya rencana tertulis bagi pengajaran tapi juga memberikan pedoman yang dapat mengatur lingkungan dan suatu kegiatan yang akan berlangsung di dalam kelas. Menurut Hilda Taba (1962) dalam Majid (2014) perbedaan antara kurikulum dan pengajaran bukan terletak pada implementasinya, tetapi pada keluasan cakupannya. Keberhasilan sekolah Islam Terpadu dalam mengembangkan standar pendidikan yang khas dengan kata 'Terpadu' termasuk juga dalam pengembangan kurikulum 'Islam' yang membuat kepercayaan masyarakat seolah memberikan 'pesona' (daya tarik) yang berbeda dari kurikulum yang ditawarkannya, pendidikan moral peserta didik menjadi 'trademark' SIT di mata masyarakat. Pada aspek pengembangan kurikulum, sekolah Islam terpadu memberikan porsi yang lebih pada pembelajaran tambahan (hidden curriculum) yang berhubungan dengan pendidikan agama seperti hafalan beberapa juz dalam Alquran (Marannu, 2017).

Kurikulum pada Jaringan Sekolah Islam Terpadu (JSIT) pada umumnya melengkapi kurikulum nasional. Didalam kurikulum Jaringan Sekolah Islam Terpadu (JSIT) seluruh mata pelajaran wajib melakukan internalisasi pada nilai-nilai Islam didalamnya (Robingatin, 2015). Pada dasarnya perpaduan antara mata pelajaran umum dengan mata pelajaran keagamaan menjadikan suatu ciri khas di dalam struktur Kurikulum Sekolah Islam Terpadu (SIT). Sekolah Islam Terpadu tidak memisahkan mata pelajaran keduanya tetapi menjadikan mata pelajaran keagamaan yang fardhu'ain untuk dipelajari dan menjadikan pelajaran umum menjadi fardhu khifayah untuk dipelajari, namun kedua-duanya merupakan rumpun keilmuan yang wajib dipelajari sebagai bekal dalam menjalankan tuga umat manusia sebagai kholifah Allah di muka bumi. Kedua rumpun keilmuan tersebut dianggap sebagai pelajaran yang sama- sama mempelajari ayat-ayat Allah SWT (Mualimin, 2017). Pada dasarnya sekolah Islam terpadu merupakan perubahan atas kegagalan yang dilakukan pada sekolah umum dan lembaga pendidikan Islam, dalam memadupadankan ilmu umum dan ilmu agama. Sehingga di dalam praktiknya, sekolah Islam terpadu melakukan pengembangan kurikulum dengan cara memadukan kurikulum pendidikan umum yang ada di Kementrian Pendidikan Nasional (Kemendiknas), seperti pelajaran 
matematika, bahasa indonesia, bahasa inggris, ipa, ips dan lain-lain, serta kurikulum pendidikan agama islam yang ada di Kementrian Agama (Kemenag), ditambang dengan kurikulum hasil kajian dari JSIT (Yusup, 2018).

\section{Pengajaran Matematika Berbasis Kurikulum JSIT}

Pembelajaran matematika bertujuan untuk mengembangkan suatu kemampuan dalam memecahkan masalah, komunikasi matematis, dengan menghubungkan suatu ide antar matematika atau dengan ilmu lain. Efek yang dapat ditimbulkan akibat belajar matematika yaitu pembentukan karakter pada siswa (Kumaryono \& Maharani, 2017). Pembelajaran matematika akan menjadi pelajaran yang tidak bermakna bagi setiap siswa, bila mereka belum mampu mengimplementasikan konsep matematika tersebut ke dalam konteks kehidupan sehari-hariWawasan dalam berpikir logis dan kritis juga sangat dibutuhkan demi perkembangan dan kemajuan dalam pembelajaran kedepannya (Azizah et al., 2018).

Tujuan pendidikan matematika pada dasarnya lebih ditekankan kepada penataan penaralan, dasar pembentukan suatu sikap, serta keterampilan siswa dalam penerapan matematika.(Firmanti, 2017). Dalam tujuan umum pendidikan matematika bisa dikatakan bahwa ada beberapa aspek-aspek yang harus ditekankan kepada pada peserta didik yaitu diantaranya: 1) Dapat memahami konsep matematika, 2) Dapat menggunakan suatu penalaran pada pola dan sifat. 3) Memecahkan suatu masalah. 4) Mengkomunikasikan suatu gagasan dengan menggunakan simbol, tabel, diagram, atau media lain untuk memperjelas suatu keadaan atau masalah. 5) Mempunyai sikap menghargai kegunaan matematika dalam kehidupan sehari-hari (Mariam et al., 2019).

Penyampaian materi dalam pembelajaran matematika hendaknya dapat dirancang dengan baik. Sehingga dapat dijadikan sebagai wahana dalam membelajarkan karakter yang positif kepada setiap peserta didik. Pembelajaran yang demikian perlu dilakukan oleh tenaga pendidik secara konsisten sehingga akan menimbulkan kebiasaan bagi setiap peserta didik (Rudyanto \& Retnoningtyas, 2018). Salah satu pembentukan karakter yang dapat digunakan pada pembelajaran matematika adalah dengan mengintegrasikannya pada kurikulum Jaringan Sekolah Islam Terpadu. Berikut adalah hasil wawancara dengan guru matematika SMPIT Arrozaq Rantauprapat:

Pertanyaan: Bagaimana kombinasi kurikulum JSIT terhadap pembelajaran matematika di SMPIT Arrozak?

Jawaban: Menurut saya kombinasi kurikulum di SMPIT Arrozaq untuk pembelajaran matematika cara pengajarannya materi yang di ajarkan di padukan dengan Al-Qur'an, bukan hanya dalam pembelajaran matematika saja, tetapi semua pembelajaran yang berada di SMPIT Arrozak harus didasar oleh Al-Qur'an. Contohnya dalam pembelajaran matematika pada materi pembagian, nah, materi pembagian itu diambil dari Surah An-nisa yang berkaitan tentang pembagian harta pusaka. Contoh lainnya pada materi kelas VIII tentang koordinat cartesius yang menyangkut tentang vertical dan horizontal, jika garis keatas itu diibaratkan bersamaan dengan Allah sedangkan garis 
vertical itu diibaratkan bersamaan dengan manusia, jadi segala sesuatunya itu berkaitan dengan Al-Qur'an dan Sunnah.

Pertanyaan: Bagaimana cara pengajaran bidang studi matematika berbasis kurikulum JSIT di SMPIT Arrozaq, apakah cara pengajarannya berbeda dengan SMP pada umumnya?

Jawaban: Menurut pendapat saya, cara pengajarannya itu berbeda, karena dalam pengajaran bidang studi matematika itu cara pengajarannya selalu digunakan dengan praktek, tidak monoton untuk mencatat rumus-rumus, intinya cara pengajaran matematika itu selalu dikaitkan dengan islam.

Pertanyaan: Apakah ada kendala yang terjadi di saat proses belajar mengajar matematika dengan menerapkan kurikulum JSIT?

Jawaban: Menurut saya untuk sejauh ini, tidak ada masalah atau kendala yang terjadi dalam proses pembelajarannya, cuman terkadang disaat saya menjelaskan pasti ada siswa yang paham dan tidak paham, tapi itukan sudah biasa, di sekolah lain pun pasti ada yang sama seperti itu.

Pertanyaan: Bagaimana hasil pembelajaran siswa dalam bidang studi matematika?

Jawaban: Untuk hasil pembelajaran sehari-hari ketika saya mengajar secara langsung itu mereka paham tentang apa yang saya ajarkan, mala mereka antusias untuk bertanya tentang materi yang dibahas, tetapi di saat proses belajar secara daring ini mereka itu kurang memahami apa yang saya ajarakan.

Dari hasil pembahasan di atas dapat di simpulkan bahwa SMPIT Arrozaq dalam melaksanakan proses belajar mengajar selalu menerapkan kurikulum JSIT dengan cara pengajaran materi yang di ajarkan di padukan dengan Al-Qur'an. Di dalam pembelajaran matematika, cara pembelajarannya selalu di lakukan dengan praktek tidak terlalu monoton kepada materi, dan proses pembelajaran selalu dikaitan dengan kehidupan sehari-hari yang berbaur ke nilai-nilai islam. Dan di dalam proses belajar mengajar, setiap siswa pasti ada yang dapat memahami materi dan tidak paham terhadap materi yang sudah diajarkan, namun jika di lihat dari hasil belajar mereka sangat antusias dalam bertanya dan ingin tahu perihal materi mana yang mereka tidak pahami.

\section{Pembentukan Karakter Melalui Kurikulum JSIT}

Pembelajaran merupakan salah satu kegiatan yang memiliki nilai edukatif yang dapat di artikan sebagai nilai-nilai yang di dalamnya mencakup sikap individu dalam kehidupan pribadi maupun sosial (Bahri,2010). Pembelajaran dianggap bukan lagi merupakan usaha untuk menyampaikan suatu pengetahuan tetapi juga dapat merubah perilaku peserta didik kea rah yang lebih baik, dan dapat menyembangkan antara kecerdasan akademik, emosional dan spiritual. Hal ini sebagaimana menjadikan orientasi kurikulum 2013 yang menyatakan bahwa tujuan kurikulum 2013 yaitu terjadinya 
peningkatan keseimbangan antara kompetensi spiritual, sikap (attitude), keterampilan (skill), dan pengetahuan (knowledge) yang bertujuan untuk membentuk karakter peserta didik (Muhsinin et al., 2019). Penguatan dalam pendidikan karakter merupakan upaya yang sangat penting untuk mencapai suatu tujuan dalam pendidikan nasional. Pendidikan karakter harus ditanamkan sejak usia dini, dengan menjadikan fondasi utama dalam pembentukan karakter pada bangsa, mengingat pentingnya pendidikan karakter tersebut maka seorang pendidik harus melakukan suatu upaya dalam mengenalkan dan mengembangkan pindidikan karakter bagi peserta didik. Salah satu upaya untuk menguatkan karakter peserta didik di sekolah yaitu melalui cara dalam membiasakan berakhlak yang mulia (Alawi, 2019).

Pendidikan karakter merupakan suatu upaya dalam membantu tenaga pendidik untuk mempersiapkan generasi bangsa yang berkualitas, serta siap dan mampu dalam menghadapi suatu tantangan di masa depan. Pendidikan karakter juga merupakan suatu pendekatan secara langsung pada pendidikan moral, yakni mengajari siswa dengan pengetahuan moral dasar untuk mencegah mereka melakukan tindakan yang tidak bermoral dan membahayakan orang lain dan dirinya sendiri (Pertiwi \& Marsigit, 2017). Implementasi dalam pendidikan karakter di sekolah juga dapat dilaksanakan dengan berbagai strategi khusus. Hal ini dilakukan untuk mencapai tujuan pembelajaran dalam membentuk karakter siswa. Selain kemampuan kognitif, afektif dan psikomotorik. Strategi pembelajaran karakter di sekolah dapat disusun dan mengacu pada strategi pembelajaran yang telah diterapkan di sekolah tersebut seperti pengembangan budaya di sekolah, kegiatan ekstrakulikuler, serta kegiatan sehari- hari siswa baik itu di rumah maupun di masyarakat (Asdarina \& Arwinda, 2020).

Pendidikan karakter juga merupakan suatu upaya yang mendasar dalam menciptakan situasi proses belajar yang memenuhi kebutuhan pengembangan diri pada siswa dalam interaksi belajar yang akan dirancang untuk membentuk siswa yang berkarakter. Meskipun demikian pembentukan dan pengembangan karakter dapat dilakukan di rumah melalui bimbingan dari orang tua dan lingkungan sekitar, namun sekolah juga berperan penting dalam pembentukan karakter pada siswa. Dengan harapan, bahwasannya melalui pendidikan karakter dapat menjadikan siswa sebagai sosok yang bertaqwa kepada Tuhan Yang Maha Esa, memiliki keimanan yang kuat sehingga dapat melahirkan pribadi yang berbudi luhur, toleran terhadap sesama, memiliki motivasi juang, mampu bekerja keras, berprestasi dan disiplin, sikap menghargai orang lain dan demokratis, bertanggung jawab, kreatif dan mandiri (Kartikasari \& Mujib, 2020).

Pertanyaan: Bagaimana karakter siswa dalam mengikuti pembelajaran matematika di SMPIT Arrozaq?

Jawaban: Karakter siswa dalam proses belajar matematika disini Alhamdulillah baik, karena memang dari kelas VII sudah dibiasakan model pembelajarannya itu selalau di awali dengan salam dan berdoa. 
Pewawancara: Apakah seluruh tenaga pendidik memahami prinsip-prinsip pembentukan karakter siswanya masing-masing?

Jawaban: Alhamdulillah iya, karena sebelum masuk ajaran baru tenaga pendidik disini selalu diadakan pelatihan khusus tentang sekolah JSIT, agar tenaga pendidik bisa proses belajar mengajar dapat diselaraskan dan satu tujuan dengan kurikulum JSIT. Jadi setiap tenaga pendidik wajib mengikuti pelatihan tersebut.

Pertanyaan: Bagaimana Penerapan Kurikulum JSIT dalam Pembentukan Karakter Siswa di SMPIT Arrozak?

Jawaban: Di SMPIT Arrozak ini contoh penerapannya bisa di lihat dalam kegiatan sehari-hari seperti melaksanakan sholat dhuha yang wajib dilakukan. Selanjutnya seperti melaksanakan sholat berjamaah, tilawah, dan dzikir bersama, jadi pada dasarnya semua penerapan yang dilakukan dan yang dilaksanakan siswa itu, dapat dirangkul untuk mendapatkan suatu kebaikan.

Pertanyaan: Karakter siswa seperti apa yang dapat di bentuk jika cara pembelajarannya berpatokan dengan kurikulum JSIT?

Jawaban: Karakter yang ingin di bentuk pada setiap siswa itu yang paling pertama adalah karakter yang bisa membawa siswa tersebut kedalam ilmu agama. Seperti membiasakan mereka melaksanakan sholat Dhuha, sholat berjamaah dan lain-lain.

Dari hasil wawancara di atas dapat di simpulkan bahwa dalam pembentukan karakter siswa melalui kurikulum JSIT di SMPIT Arrozaq sudah baik, karena dari awal mereka sudah di tanamkan sifat jujur dan berprilaku sopan dan santun, dan model pembelajaran yang dilakukan juga selalu di awali dengan salam dan berdoa. Tenaga pendidik di SMPIT Arrozaq juga memahami prinsip-prinsip pembentukan karakter pada siswanya masing-masing, karena sebelum masuk ajaran baru tenaga pendidik di SMPIT Arrozaq selalu diadakan pelatihan khusus tentang sekolah JSIT dan tentang kurikulum JSIT, tujuannya yaitu agar tenaga pendidik disini bisa melakukan proses belajar mengajar dengan menselaraskan dan satu tujuan dengan kurikulum JSIT. Penerapan kurikulum JSIT dalam pembentukan karakter siswa di SMPIT Arrozaq dapat di lihat dalam kegiatan sehari-hari mereka seperti melaksanakan sholat dhuha yang wajib dilakukan. Selanjutnya melaksanakan sholat berjamaah, tilawah, dan dzikir bersama, jadi pada dasarnya semua penerapan yang dilakukan dan yang dilaksanakan siswa itu, dapat dirangkul untuk mendapatkan suatu kebaikan. Karakter yang ingin dibentuk dalam proses pembelajaran yang berpatokan dengan kurikulum JSIT yaitu karakter bisa membawa siswa tersebut kedalam ilmu agama. 


\section{Kelebihan dan Kekurangan Kurikulum JSIT}

Pada dasarnya dalam bidang pendidikan, kurikulum merupakan unsur yang paling penting dalam setiap bentuk dan model pendidikan manapun. Tanpa adanya kurikulum, maka akan sulit rasanya bagi seorang pendidik dlam mencapai tujuan pendidikan yang akan diselenggarakan. Kurikulum pendidikan islam memiliki lima ciri utama yang dapat membedakannya dengan kurikulum secara umum lima ciri tersebut yaitu: a. Kurikulum pendidikan Islam yang menonjol dan mengutamakan agama dan akhlak dalam berbagai tujuan yang dilakukan. b. Cakupan dan kandungan dari kurikulum yang bersifat luas dan menyeluruh. c. Kurikulum pendidikan Islam yang menerapkan prinsip keseimbangan di dalam muatan materi keilmuannya. d. Kurikulum pendidikan Islam yang mencakup keseluruhan mata pelajaran yang sangat dibutuhkan oleh peserta didik. e. Kurikulum pendidikan Islam yang selalu tersusun berdasarkan kesesuaian dengan minat serta bakat peserta didik (Indra \& Barat, n.d.).

Kurikulum dalam pengembangan Sekolah Islam Terpadu sangat berperan penting dalam penggambaran konsep keterpaduannya. Seluruh sekolah Islam terpadu yang tersebar di Indonesia telah memiliki kurikulum khas Sekolah Islam terpadu. Kurikulum pada sekolah Islam terpadu tersebut dinamakan dengan (kurikulum ke-Islam Terpadu-an), sudah merupakan kurikulum yang telah dirumuskan oleh pengurus pusat JSIT lewat musyawarah nasional, dan sudah disetujui oleh dewan pembina yang kemudian dapat diteruskan ataupun harus diterapkan oleh seluruh sekolah yang bergabung dalam jaringan sekolah Islam terpadu. Kurikulum sekolah Islam terpadu berhasil membawa dampak yang cukup signifikan dalam proses belajaran mengajar yang berjalan di dalam suatu kelas. Dampak ini biasa disebut dengan dampak Islamisasi kelas atau dampak Islamisasi pembelajaran. Disebut demikian karena kurikulum sekolah Islam terpadu sudah mampu mengintegrasikan nilai-nilai Islam ke dalam berbagai mata pelajaran non pendidikan agama Islam. Bahkan indikator pencapain belajar siswa tidak hanya diukur dengan tercapainya sebuah kompetensi, akan tetapi yang lebih ditekankan yaitu sejauh mana siswa dapat berkomitmen dengan pembelajaran nilai-nilai Islam yang telah mereka pelajari (Rojii et al., 2019).

Kurikulum yang dikembangkan sebaiknya dapat memperhatikan perkembangan dan kemampuan akademik pada peserta didik, dalam memahami pembelajaran serta dapat memperhatikan kehidupan sosial di masyarakat. (Sudjana dalam Gunawan 2012) menjabarkan isi kurikulum yang dapat menentukan berhasilnya suatu tujuan yang ingin di capai, yaitu sebagai berikut: (1) Isi kurikulum harus sesuai dengan perkembangan siswa atau peserta didik, artinya sejalan dengan tahap perkembangan pada anak. (2) Isi kurikulum dapat mencerminkan kenyataan sosial, artinya sesuai dengan tuntutan kehidupan yang nyata dalam masyarakat. (3) Isi kurikulum dapat mencapai tujuan yang komprehensif, artinya mengandung pada aspek intelektual, moral, dan sosial yang seimbang. (4) Isi kurikulum harus mengandung pengetahuan ilmiah yang tahan uji artinya tidak cepat rapuh hanya karena perubahan tuntutan dalam kehidupan sehari-hari. (5) Isi kurikulum harus mengandung bahan pelajaran yang jelas, memiliki teori, prinsip, dan konsep yang terdapat di dalamnya bukan hanya sekedar informasi yang factual. (6) Isi kurikulum harus dapat menunjang tercapainya suatu tujuan pendidikan yang nantinya 
dapat dijabarkan dan dilaksanakan melalui proses pengajaran/pengalaman belajar pada peserta didik (Nugroho et al., 2019).

Kurikulum SIT pada dasarnya sangat berbeda dari kurikulum sekolah umum. Di dalam kurikulum SIT beban pendidikan agama lebih dari beban sekolah biasanya. Selain itu, banyak juga amalan keagamaan seperti melaksanakan sholat dhuha, puasa, dan mengaji. Sederhananya, kurikulum SIT jauh lebih mirip dengan madrasah dimana pengetahuan agama lebih diberikan banyak porsi. Dimensi dalam praktik keagamaan di SIT lebih tebal dari pada di sekolah negeri. Praktik yang selalu dilakukan di SIT seperti melaksanakan sholat (Jemaah, dzuhur, ashar, dhuha) tilawah tahfidz yang menjadi kebiasaan di sekolah tersebut. Padahal kebiasaan baik ini tidak serta merata dilakukan di rumah atau tempat lain (Sofanudin, 2019).

Pertanyaan: Menurut ibu apa Kelebihan dan Kekurangan kurikulum JSIT?

Jawaban: Menurut saya kelebihan kurikulum JSIT itu pembahasan lebih banyak terkait ke pembahasan ipa, sedangkan ke pembahasan matematika itu lebih sedikit, jadi disini tenaga pendidik harus pandai mengelola bagaimana cara penerepan kurikulum JSIT itu ke pembelajaran matematika.

Dari hasil wawancara diatas dapat disimpulkan bahwa menurut ibu Nadrah Hasibuan S. Pd, kelebihan dan kekurangan kurikulum JSIT itu terletak pada pembahasannya lebih banyak terkait ke pembahasan ipa, sedangkan ke pembahasan matematika itu lebih sedikit, jadi disini tenaga pendidik harus pandai mengelola bagaimana cara penerepan kurikulum JSIT itu ke pembelajaran matatematika

\section{Hasil Observasi}

Dari hasil observasi yang di dapatkan di SMPIT Arrozaq bahwa di dalam sekolah tersebut sebelum seluruh siswa melaksanakan proses belajar mengajar di dalam kelas, siswa melakukan apersepsi untuk mendengarkan arahan yang disampaikan oleh guru. Arahan ini berisi tentang nasehat bagi siswa dalam berperilaku baik dan bersikap jujur di dalam sekolah. Selesai melaksanakan apersepsi, sebelum memasuki ruangan kelas, siswa tersebut melakukan setoran hafalan surah-surah pendek yang telah ditentukan sebelumnya oleh guru. hal ini dilakukan agar para guru dapat melihat bagaimana seorang siswa bersungguh-sungguh melaksanakan tugasnya dalam menghafal ayat- ayat Al-Qur'an. Sebelum memulai proses pembelajaran guru mengucapkan salam dan memulai pembelajaran. Di saat proses belajar mengajar sebelum tenaga pendidik menyampaikan materi yang akan di sampaikan, terlebih dahulu ia menanyakan kepada siswa tentang materi minggu lalu apakah siswa tersebut masih mengerti atau tidak, setelah menanyakan materi sebelumnya, tenaga pendidik memulai pembelajaran yaitu tentang materi SPLDV (sistem persamaan dua variabel) yang akan di sampaikan dengan mengkaitkannya materi tersebut kedalam ke hidupan sehari-hari. Pada proses belajar mengajar dikelas VIII Baihaqi terlihat bahwa hampir semua siswa memiliki karakter baik, sopan, santun dan ramah dalam 
menjawab pertanyaan yang di berikan oleh guru. Namun salah satu dari mereka tidak memperhatikan pembelajaran yang sedang berlangsung, salah satu siswa ada yang sedang tidur di saat proses belajar mengajar, guru tersebut menegurnya, dan menyuruh siswa tersebut untuk mengambil air wudhu, hal ini biasa dilakukan agar siswa tersebut memiliki pikiran yang bersih dan mata yang cerah dalam mengikuti proses pembelajaran. Setelah penjelasan materi dan contoh soal selesai disampaikan, Guru memberikan satu soal tentang materi SPLDV. Hal ini dilakukan untuk melihat bagaimana siswa tersebut paham atau tidak tentang materi yang sudah di jelaskan. Guru berkata apabila ada salah satu siswa tercepat dan benar dalam mengerjakan soal tersebut maka ia mendapatkan reward yang di berikan oleh guru. Karakter yang terlihat saat guru menyampaian tentang reward semua siswa sangat antusias dalam mengerjakan soal yang di berikan, tetapi saat pengumpulan jawaban dari 25 siswa perempuan di kelas VIII Baihaqi hanya $12 \%$ yang menjawabnya dengan benar.

\section{KESIMPULAN}

Berdasarkan hasil uraian dalam pembahasan diatas mengenai implementasi pembelajaran matematika berbasis kurikulum Jaringan Sekolah Islam Terpadu (JSIT) dalam pembentukan karakter Siswa di SMPIT Arrozaq dapat ditarik kesimpulan bahwa konsep kurikulum yang dilaksanakan di SMPIT Arrozaq yaitu memadukan kurikulum Kementerian Pendidikan dan Kebudayaan (Kemendikbud) dengan kurikulum Kementrian Agama (Kemenag) dan kurikulum khas sekolah Islam yakni kurikulum JSIT dengan menerapkan konsep materi pembelajaran yang berpedoman pada kehidupan sehari-hari dan berpatokan dengan Al-Qur'an. Nilai-nilai karakter diimplementasikan di SMPIT Arrozaq di lihat dari kegiatan yang dilakukan sehari-hari seperti melaksanakan sholat berjamaah, tilawah, dan dzikir bersama, jadi pada dasarnya semua penerapan yang dilakukan dan yang dilaksanakan siswa itu, dapat dirangkul untuk mendapatkan suatu kebaikan.

\section{REFERENSI}

Alawi, A. H. I. (2019). Pendidikan Penguatan Karakter Melalui Pembiasaan Akhlak Mulia (Studi SD IT Asy Syifa Kota Bandung). Jurnal Qiro'ah, 9(1), 17-29.

Asdarina, O., \& Arwinda, N. (2020). Analisis Implementasi Pendidikan Karakter dalam Proses Pembelajaran Matematika. Mathema Journal, 2(1), 1-11.

Azizah, M., Sulianto, J., \& Cintang, N. (2018). Analisis Keterampilan Berpikir Kritis Siswa Sekolah Dasar pada Pembelajaran Matematika Kurikulum 2013. Jurnal Penelitian Pendidikan, 35(1), 6170. https://doi.org/10.15294/jpp.v35i1.13529

Erwanto, E. (2019). Penerapan Kurikulum Jaringan Sekolah Islam Terpadu (Jsit) Dalam Pembentukan Karakter Religius Siswa Smpit Khoiru Ummah Rejang Lebong. Al-Bahtsu: Jurnal Penelitian Pendidikan Islam, 4(Vol 4, No 1 (2019): Juni), 71-84. https://ejournal.iainbengkulu.ac.id/index.php/albahtsu/article/view/1994

Fahri, M. (2018). Nilai-Nilai Karakter Sekolah Dasar Islam Terpadu Nurul Fikri Depok. JMIE (Journal of Madrasah Ibtidaiyah Education), 2(1), 131. https://doi.org/10.32934/jmie.v2i1.59 
Firmanti, P. (2017). Penalaran Siswa Laki-laki dan Perempuan dalam Proses Pembelajaran Matematika. HUMANISMA: Journal of Gender Studies, 1(2), 73-85.

Indra, R., \& Barat, S. (n.d.). Implementasi standar mutu kekhasan jaringan sekolah islam terpadu pada smp it iqra' kota solok. 113-128.

Kartikasari, D., \& Mujib, Z. (2020). Hambatan Pengimplementasian Kurikulum 2013 Pada Proses Pembelajaran Universalime Islam (PAI). Belajea; Jurnal Pendidikan Islam, 5(2), 181. https://doi.org/10.29240/belajea.v5i2.1606

Kumaryono, I., \& Maharani, H. R. (2017). Penerapan Pembelajaran Berkarakter Islami Pada Program PPL Mahasiswa Pendidikan Matematika Unissula Semarang. Suska Journal of Mathematics Education, 3(2), 119. https://doi.org/10.24014/sjme.v3i2.4046

Marannu, B. (2017). Pesona Kurikulum SMP Islam Terpadu 'Al-Qalam' Kota Kendari. Pusaka, 5(2), 235-256. https://doi.org/10.31969/pusaka.v5i2.182

Mariam, S., Nurmala, N., Nurdianti, D., Rustyani, N., Desi, A., \& Hidayat, W. (2019). Analisis Kemampuan Pemecahan Masalah Matematis Siswa MTsN Dengan Menggunakan Metode Open Ended Di Bandung Barat. Jurnal Cendekia: Jurnal Pendidikan Matematika, 3(1), 178-186. https://doi.org/10.31004/cendekia.v3i1.94

Maryati, I. (2017). P Embelajaran K Ontekstual. 6(September), 333-344.

Mualimin. (2017). Abstrak PENDAHULUAN Menjelang abad ke 21 , model lembaga pendidikan di Indonesia hanya mengenal tiga model lembaga pendidikan yakni pesantren, madrasah, dan sekolah ( umum ) ( Azhari \& Saleh , 1989 ). Pesantren merupakan lembaga pendidikan Islam tradisi. Jurnal Pendidikan Islam, 8(I), 99-116.

Muhsinin, U., Musyaddad, K., \& Azim, F. (2019). Implementasi Pembelajaran Tematik Integratif Berbasis Karakter Di Sdit Kota Jambi. Al-Tadzkiyyah: Jurnal Pendidikan Islam, 10(1), 51-68. https://doi.org/10.24042/atjpi.v10i1.3626

Nizarani. (2019). Manajemen Pendidikan Karakter Sekolah Islam Terpadu Berbasis Pesantren. Prosiding Seminar Nasional Program Pascasarjana Universitas PGRI Palembang, April 2018, $1134-1147$. palembang.ac.id/index.php/Prosidingpps/article/download/2674/2478 https://jurnal.univpgri-

Nugroho, M. B., ربانى ع., Strathern, P., Äüôú, Ö., Strathern, P., Geordane, M. H., Mendonça, F. D. A., Strathern, P., Arist, P. S., Russell, B., Agostinho, S., Strathern, P., Lúcia De Oliveira, M., Russell, B., Agostinho, S., Roberto, T. :, Valente, F., Anggraini, A. R., Oliver, J., ... Scobell, A. (2019). 済無No Title No Title. Journal of Chemical Information and Modeling, 53(9), 1689-1699. file:///C:/Users/User/Downloads/fvm939e.pdf

Pertiwi, I., \& Marsigit, M. (2017). Implementasi pendidikan karakter dalam pembelajaran matematika SMP di Kota Yogyakarta. Jurnal Riset Pendidikan Matematika, 4(2), 153. https://doi.org/10.21831/jrpm.v4i2.11241

LEXY J. MOLEONG, M. . (2013). Metodologi Penelitian Kualitatif (M. . PROFf.DR.LEXY J. MOLEONG (ed.); Revisi). PT REMAJA ROSDAKARYA.

Sugiono. (2009). Metode Penelitian Pendidikan Pendekatan Kuantitatif, Kualitatif, dan R\&D. CV.Alfabrta.

Robingatin, S. (2015). Implementasi Kurikulum Jaringan Sekolah Islam Terpadu di Sekolah Menengah Pertama Islam Terpadu. SYAMIL: Jurnal Pendidikan Agama Islam (Journal of Islamic Education), 3(1), 127-154. https://doi.org/10.21093/sy.v3i1.241 
Rojii, M., Istikomah, I., Aulina, C. N., \& Fauji, I. (2019). DESAIN KURIKULUM SEKOLAH ISLAM TERPADU (Studi Kasus di SMPIT Insan Kamil Sidoarjo). Al-Tanzim: Jurnal Manajemen Pendidikan Islam, 3(2), 49-60. https://doi.org/10.33650/al-tanzim.v3i2.667

Rudyanto, H. E., \& Retnoningtyas, W. A. (2018). Integrasi nilai - nilai karakter melalui pembelajaran matematika di sekolah dasar. Prosiding Konferensi Ilmiah Dasar, 1(7), 34-43. http://prosiding.unipma.ac.id/index.php/KID

Sofanudin, A. (2019). Tipologi Kurikulum Pendidikan Agama Islam Pada Sekolah Islam Terpadu ( Sit ) Curriculum Typology of Islamic Religion Education in. 17(1), 42-56.

Suyatno, S. (2015). Sekolah Islam Terpadu Dalam Peta Sistem Pendidikan Nasional. Alqalam, 32(2), 309. https://doi.org/10.32678/alqalam.v32i2.553

Yusup, M. (2018). Eksklusivisme Beragama Jaringan Sekolah Islam Terpadu (Jsit) Yogyakarta. Religi Jurnal Studi Agama-Agama, 13(01), 75. https://doi.org/10.14421/rejusta.2017.1301-05 